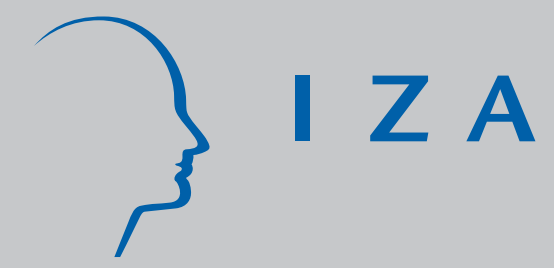

IZA DP №. 3017

Individual and J ob-Based Determinants of

Performance Appraisal: Evidence from Germany

Christian Grund

Dirk Sliwka

August 2007 


\title{
Individual and Job-Based Determinants of Performance Appraisal: Evidence from Germany
}

\author{
Christian Grund \\ University of Wuerzburg \\ and IZA
}

Dirk Sliwka

University of Cologne

and IZA

\author{
Discussion Paper No. 3017 \\ August 2007 \\ IZA \\ P.O. Box 7240 \\ 53072 Bonn \\ Germany \\ Phone: +49-228-3894-0 \\ Fax: +49-228-3894-180 \\ E-mail: iza@iza.org
}

\begin{abstract}
Any opinions expressed here are those of the author(s) and not those of the institute. Research disseminated by IZA may include views on policy, but the institute itself takes no institutional policy positions.

The Institute for the Study of Labor (IZA) in Bonn is a local and virtual international research center and a place of communication between science, politics and business. IZA is an independent nonprofit company supported by Deutsche Post World Net. The center is associated with the University of Bonn and offers a stimulating research environment through its research networks, research support, and visitors and doctoral programs. IZA engages in (i) original and internationally competitive research in all fields of labor economics, (ii) development of policy concepts, and (iii) dissemination of research results and concepts to the interested public.
\end{abstract}

IZA Discussion Papers often represent preliminary work and are circulated to encourage discussion. Citation of such a paper should account for its provisional character. A revised version may be available directly from the author. 
IZA Discussion Paper No. 3017

August 2007

\section{ABSTRACT \\ Individual and Job-Based Determinants of Performance Appraisal: Evidence from Germany}

We investigate the use of performance appraisal (PA) in German Firms. First, we derive hypotheses on individual and job based determinants of PA usage. Based on a representative German data set on individual employees, we test these hypotheses and also explore the impact of PA on performance pay and further career prospects. The results include that PA is positively linked to an individual's willingness to take risks. The performance of older employees and woman is evaluated less often. Furthermore, larger firms evaluate the performance of their employees more. We find evidence for a nonmonotonic relation between the hierarchical level and usage of performance appraisal: The performance of employees with very high or very low responsibilities is assessed less often.

JEL Classification: J33, M52

Keywords: performance appraisal, performance evaluation, GSOEP

Corresponding author:

Christian Grund

University of Würzburg

Am Sanderring 2

D-97070 Würzburg

Germany

E-mail: christian.grund@uni-wuerzburg.de 


\section{Individual and J ob-Based Determinants of Performance Appraisal - Evidence from Germany}

\section{Introduction}

Performance appraisal (PA) systems are among the most important human resource practices and also a comprehensively discussed research topic. Bretz et al. (1992) as well as Levy and Williams (2004) for instance provide extensive reviews of the huge literature on appraisals. Key topics of the contributions in academic journals include information processes, rating errors, reactions to the appraisal process, as well as rater training, appraisal feedback and group dynamics. Recent contributions for instance analyze the consequences of PA on employee job satisfaction, turnover intention and performance (Callahan et al. 2003, Poon 2004, Kuvaas 2006). But the relevant empirical studies usually examine a limited number of observations and analyze an existing system in one or only a few firms.

Surprisingly little research has been conducted about the determinants of formal performance appraisal systems. For instance, Murphy and Cleveland (1995, p. 36) point out that "there is very little empirical research on the links between environmental variables and appraisal”. An exception is a recent study by Brown and Heywood (2005) who analyze Australian data to investigate the determinants of performance appraisal systems, which include union coverage and firm size. However, they use establishment data and therefore cannot investigate which personal characteristics of an employee influence whether she or he works on job where performance is regularly appraised.

In this contribution, we study individual as well as job characteristics determining the use of performance appraisal by a supervisor in German firms. Moreover, we are able to distinguish between different consequences of appraisal results. We evaluate a new set of variables of the German Socio Economics Panel (GSOEP), a representative survey of the German population. 
The DIW (German Institute for Economic Research), which administrates the survey, followed our proposal to include questions on performance appraisals in the 2004 wave of the GSOEP. As the GSOEP contains a large set of questions on individual characteristics of the respondents as well as on their jobs and employers, this offers a unique opportunity to investigate determinants, the general incidence of performance appraisal systems and consequences of appraisal results in a representative survey of the German working population.

The paper is organized as follows: We first derive hypotheses about several possible individual and job based determinants of the use of PA (section 2). We then test these hypotheses with the data of the GSOEP and examine the consequences of PA for employees (section 3). Section 4 concludes.

\section{Theoretical Considerations and Hypotheses}

The introduction of formal appraisal systems is often guided by multiple goals. Cleveland et al. (1989) for instance distinguish several categories of use: First, appraisals are used to make between-person decisions, for instance for promotions or termination decisions or salary administration. Second, PA may be used for within person decisions, to determine competency profiles and strengths and weaknesses for instance in order to give performance feedback and discover training needs. Furthermore, organizational aspects such as system maintenance (e.g. personnel planning) and documentation are other possible purposes of PA. A survey by Cleveland et al. (1989) shows that appraisals have the greatest impact on salary administration, performance feedback and identification of strengths and weaknesses

Given the different possible reasons to use appraisal systems, there are several individual and job based characteristics which should determine whether a person works in a job in which her or his performance is appraised in a systematic manner.

\subsection{Individual Characteristics}

First of all the fact that an employee's performance is evaluated should be associated with age for several reasons. For instance, the probability of a promotion will be small near the retirement age and hence, between-person comparisons based on appraisals of performance are of smaller importance for the elderly. But also the results from performance appraisals should become less important for older employees for within person decisions such as the detection of training needs. Investments in training for older employees are not as beneficial 
as for younger employees, because the amortisation period of such investments is declining in age. Hence, we expect that the performance of older employees is less likely assessed than that of younger employees.

Risk averse individuals try to avoid situations in which they are faced with income uncertainty. Since systematic performance appraisals are often a precondition for performance pay, we conclude that the willingness to take risks is positively associated with being in a job with systematic appraisals.

Clear hypotheses with regard to sex are hard to derive. One may argue that women are less willing to task risk or have a lower expected tenure due to parental leaves, which may influence compensation and PA. These arguments bring us back to the tenure and risk attitude aspect, though. Controlling for gender, however, seems to be sensible. Besides, there might also be differences between different regions of Germany because of the different history of East- and West-Germany during the second half of the $20^{\text {th }}$ century. We do not expect direct effects of an employee's education on the probability that her or his performance is appraised but rather an indirect effect. Better educated employees should work in different jobs and, as we will argue in the next subsection, the job status and hierarchical level should have an impact on the use of performance appraisals.

\subsection{Job-based and Firm Characteristics}

We expect that there should be a strong impact of firm size on the probability that an appraisal system is used for several reasons: In small owner-managed firms the employer knows most of his or her employees directly and observes their actual performance continuously even without systematic appraisals. But such direct monitoring is harder in larger firms so that the free-riding problem or social loafing should be prevalent to a stronger extend which raises the necessity of individual performance evaluation. Moreover, in larger firms it becomes more necessary to compare the performance of employees across departmental boundaries, which makes standardized methods to appraise performance more important. Furthermore, setting up a formal appraisal system causes fixed costs and, hence, the benefits of such systems are more likely to exceed the costs in larger firms. Finally, large firms typically offer more formal training so that the presence of PA systems is more likely to determine specific training needs. Arguments about the interrelation between the job status or hierarchical level and the use of PA are ambiguous. On the one hand, formal PA systems for untrained workers often seem unnecessary for instance as in those jobs simple instructions are often sufficient and 
monitoring work performance is straightforward. However, if an employee performs multiple tasks the danger of distorted incentives to allocate effort across tasks arises (see for instance Kerr (1975), Holmström/Milgrom (1991)). This should make carefully designed appraisal by the direct superior more important. From this angle, the more complex a job, the more often we should observe systematic appraisals.

On the other hand, the performance of executives cannot be rated by a hierarchical superior (other than the board) simply because they are at the top of the hierarchy. Therefore, their salaries are more often directly tied to objective performance measures and typically no systematic appraisal process should be needed. Murphy (1999) for instance finds by analyzing the "Annual Incentive Plan Design Survey" by Towers Perrin, that only less than $5 \%$ of the bonus plans for top level managers are discretionary in the sense that the bonus is determined by an appraisal by the board. Similarly, Murphy and Oyer (2003) find that such discretion is less important in determining CEO pay than the pay of other executives. Hence, we hypothesize a curvilinear interrelation between job position and the usage of PA. We should observe that performance appraisals are used most frequently for employees in the middle of a hierarchy and less frequently for employees at the bottom or at the top.

Related to issues of job complexity, the scope for performance appraisals should differ between industries. In industries such as agriculture or construction, jobs consist typically of more precisely defined tasks than for instance in financial services. Hierarchical superiors should therefore be more able to lead their employees by clearly defined assignments rather than more complex management-by-objectives. Hence, performance appraisals may be observed less frequently.

The tenure at the current employer should also influence the probability that performance is appraised systematically. The competencies of employees with longer tenure will be better known to their employers. Hence, systematic appraisal is less necessary to learn about their strengths and weaknesses either for promotion or training purposes. But on the other hand, structured appraisals are often part of a formal incentive system as they are necessary to determine the size of actual bonus payments. However, some firms use deferred compensation as an alternative possibility to generate work incentives. Deferred compensation systems, however, only make sense, if long employment duration is intended. That is why PA may be used for employment relationships of shorter expected duration as a substitute for deferred compensation or other long term incentive contracts (see Brown and Heywood 2005). When this effect dominates we should observe that performance appraisal is 
more frequent for individuals with shorter tenure. We do not know ex ante, which of these or possible other effects dominate in practice.

Finally, when comparing part time with full time employees, we expect to observe performance appraisals for part time employees less often. As part-time workers are usually less considered for promotions and training, there is less necessity for PA for this group of employees.

\section{Empirical Study}

\subsection{Data, Variables and Methodology}

We make use of the data of the German Socio Economic Panel (GSOEP), which is a large representative data set of individuals living in Germany. ${ }^{1}$ Next to demographic characteristics the survey contains information of various areas of life such as the employment relationship. We initiated that a new set of variables has been implemented in the questionnaire for the 2004 survey. Individuals were asked, whether their job performance is assessed within a formal PA system and if yes, whether the outcome of this has an impact on a bonus payment and/or possible future promotions. We investigate all employees, who are 20 to 65 years old. The sample includes information on 7,598 individuals. About 31 percent of these persons report that performance is evaluated regularly by a superior as part of a agreed procedure (Table 1).

As discussed in the section above PA may not by chance be implemented for certain individuals and jobs. Possible individual determinants include sex, age, tenure, years of schooling and risk attitude. The willingness to take risk in the occupational career is measured on a 11-point scale from 0 (unwilling to take risks) to 10 (fully prepared to take risks). Job based characteristics are job contract, job status, firm size and industry. We can distinguish between part-time and full-time workers. There are 13 job status categories, which include five blue collar, five white collar and three civil servant categories, which differ with regard to responsibility and task authority. Firm size is measured in six categories defined by the number of employees. Region represents a binary variable, which controls for possible differences between East- and West-Germany (see Table1).

\footnotetext{
${ }^{1}$ The data are provided by the German Institute of Economic Research (DIW, Berlin). See http://www.diw.de/english/sop/index.html for a detailed description of the corresponding questionnaire.
} 
Table 1: Descriptive Statistics of Variables $(n=7598)$

\begin{tabular}{|c|c|c|}
\hline Variable & Mean/ Share & Standard deviation \\
\hline Performance Appraisal (1 = yes) & 0.310 & 0.462 \\
\hline Sex (1 = Female $)$ & 0.461 & 0.499 \\
\hline Age & 42.19 & 10.08 \\
\hline Years of Schooling & 12.45 & 2.58 \\
\hline Employee’s risk attitude ${ }^{(*)}$ & 3.90 & 2.48 \\
\hline Tenure (in years) & 11.20 & 9.68 \\
\hline Part-time employee (1= yes) & 0.215 & 0.411 \\
\hline Region (1 = East Germany) & 0.239 & 0.426 \\
\hline \multicolumn{3}{|l|}{ Job Status: } \\
\hline Untrained blue collar worker & 0.031 & 0.175 \\
\hline Semi-trained blue collar worker & 0.115 & 0.319 \\
\hline Trained blue collar worker & 0.152 & 0.359 \\
\hline Foreman & 0.020 & 0.139 \\
\hline Master craftsman & 0.018 & 0.133 \\
\hline Untrained white collar worker & 0.041 & 0.198 \\
\hline Trained white collar worker & 0.093 & 0.291 \\
\hline Qualified professional & 0.280 & 0.449 \\
\hline Highly qualified professional & 0.154 & 0.361 \\
\hline Managerial position & 0.018 & 0.132 \\
\hline Low/middle level civil servant & 0.026 & 0.159 \\
\hline High level civil servant & 0.036 & 0.186 \\
\hline Executive civil servant & 0.017 & 0.128 \\
\hline \multicolumn{3}{|l|}{ Firm size: } \\
\hline 1-4 employees & 0.065 & 0.247 \\
\hline 5-19 employees & 0.157 & 0.364 \\
\hline 20-99 employees & 0.207 & 0.405 \\
\hline 100-199 employees & 0.100 & 0.300 \\
\hline 200-1999 employees & 0.231 & 0.422 \\
\hline \multicolumn{3}{|l|}{ Industry: } \\
\hline Agriculture & 0.011 & 0.104 \\
\hline Manufacturing & 0.284 & 0.451 \\
\hline Construction & 0.055 & 0.228 \\
\hline Retail, Tourism, Transportation & 0.202 & 0.402 \\
\hline Financial/Corporate Services & 0.112 & 0.315 \\
\hline Public and private Services & 0.336 & 0.473 \\
\hline
\end{tabular}

Note: ${ }^{(*)}$ Risk attitude scaled from 0 (totally unwilling to take risks in the area of the occupational career) to 10 (fully prepared to take risks). 


\subsection{Individual and J ob Based Determinants of Performance Appraisals}

We explore possible individual and job based determinants of the use of PA in two stages. First, we give an overview of the relevance of PA for different subgroups of employees by reporting shares of persons, whose performance is assessed. Second, we examine determinants with a multivariate binary probit regression, where a dummy for a PA regulation acts as the dependent variable.

As Figure 1 shows men are more often appraised than women. The share of employees with PA is increasing in their willingness to take career related risks. This confirms the riskincentive trade-off predicted by agency theory. Full-time employees are more often appraised than part-time workers. Huge differences can be observed with regard to firm size. Formal PA systems exist for only 7 percent of employees in small firms with less than five employees, whereas the performance is assessed for more than half of employees in firms with more than 2000 workers. The fraction of individuals with PA also differs considerably across industries and job status categories.

The mean age, tenure and schooling of employees whose performance is assessed do not seem to differ dramatically to those without PA (see Table 2). As expected, employees with PA are somewhat younger on average and had a longer education. All in all, these first results seem to be in line with our theoretical considerations of the previous section.

Table 2: Descriptive statistics of age, tenure and schooling

\begin{tabular}{lcccc}
\hline \multirow{2}{*}{ Variable } & \multicolumn{2}{c}{ With PA } & \multicolumn{2}{c}{ Without PA } \\
& Mean & $\begin{array}{c}\text { Standard } \\
\text { deviation }\end{array}$ & Mean & $\begin{array}{c}\text { Standard } \\
\text { deviation }\end{array}$ \\
\hline Age & 41.8 & & 42.3 & \\
Tenure & 12.3 & & 10.7 & \\
Years of Schooling & 12.9 & & 12.2 & \\
\hline
\end{tabular}

But of course it is important to investigate the determinants in a multivariate analysis. To do that we ran a binary probit regression with the binary dummy "Use of PA" as dependent variable (1=”yes", $0=$ "no"). The results are reported in Table 3 . We start with a regression including only the individual characteristics age, gender, years of schooling, and individual risk attitudes in column (1). In column (2) we report a regression in which we control only for job based characteristics and in column (3) we control both for individual and job based characteristics. 
The results from column (1) confirm that women are appraised significantly less often than men and that employees with a stronger willingness to take risks are indeed more often in jobs with performance appraisals. But there is no significant effect of age. It is quite interesting to note that a probit regression that does not include risk attitudes would show a significantly negative age effect. Hence, the age effect indicated in the descriptive statistics is in fact mainly due to risk attitudes as it disappears as we control for the latter. Indeed, there is a significant negative correlation $(-0.17)$ between age and the willingness to take risks. Although the age effect reappears when we control for job and firm based characteristics it remains only weakly significant.

When comparing the results from the different probit regressions it becomes apparent that mainly the job based characteristics are important when explaining the incidence of appraisals. This can be illustrated by comparing the pseudo $\mathrm{R}^{2}$ between the columns. Whereas the observed individual characteristics explain only about $2 \%$ of the variation in appraisals, $14 \%$ are explained by job based characteristics and the pseudo $\mathrm{R}^{2}$ does not increase when individual and firm based characteristics are combined. It turns out that especially the firm size and job status categories have a strong impact on the appraisal probability. Appraisals are more frequent in larger firms and we can confirm the inversely U-shaped relation between the frequency of appraisals and the hierarchical level for blue and white collar workers. However, we do not find effects of tenure.

The regression results confirm our initial hypothesis on the effect of firm size on performance appraisals. As expected, there are also significant industry effects. In line with our reasoning, in financial and corporate services performance appraisals are most often used and in the construction industry performance appraisals least often. Note that the multivariate analysis reveals that the industry effects observed in the descriptive statistics are influenced by interindustry differences in the distribution of job and individual characteristics. For instance, when controlling for job status, performance appraisals are used more frequently in agriculture than the descriptive statistics indicates ${ }^{2}$, which is due to the fact that agriculture has many lower level jobs and small firm sizes which both lead to a less frequent use of performance appraisals. The age effect becomes weakly significant when we control for job based characteristics.

\footnotetext{
${ }^{2}$ Note that according to the descriptive statistics, performance appraisals are for instance less often used in agriculture than in retail, tourism, transportation and public and private services. But as our estimation results indicate, when we compare employees with the same job status and within firms of the same size performance appraisals are more often used in agriculture than in these two industries.
} 
There are other interesting observations from a comparison of columns (1) and (3). Note that the results of column (1) seem to indicate that there is also a significant effect of the years of schooling on the incidence of performance appraisals. However, this effect disappears entirely when we control for job based characteristics. Individuals with higher levels of schooling simply have on average jobs on higher hierarchical levels and performance appraisals are more frequent in these jobs, which drives this result.

Furthermore, the negative effect of gender shrinks considerably when job based determinants are included. Hence, women are to a large part appraised less often as they work less often in jobs where performance appraisals are frequently used. For instance, as is well known, they are underrepresented in higher hierarchical levels in which appraisals are more common. However, it is still interesting to note that a gender effect remains even when controlling for all observable job based characteristics. This may potentially be explained by a stronger aversion of women to being controlled. Recent experimental studies (see for instance Niederle and Vesterlund 2007) indeed indicate that women tend to dislike competitive environments and appraisals may be associated with or are even a precondition for relative performance evaluations. Hence, it is quite plausible that women self select (within industries and for given job characteristics controlled in our study for) into jobs in which performance appraisals are less frequent. 
.Figure 1: Percentage of individuals, whose performance is $(n=7598)$

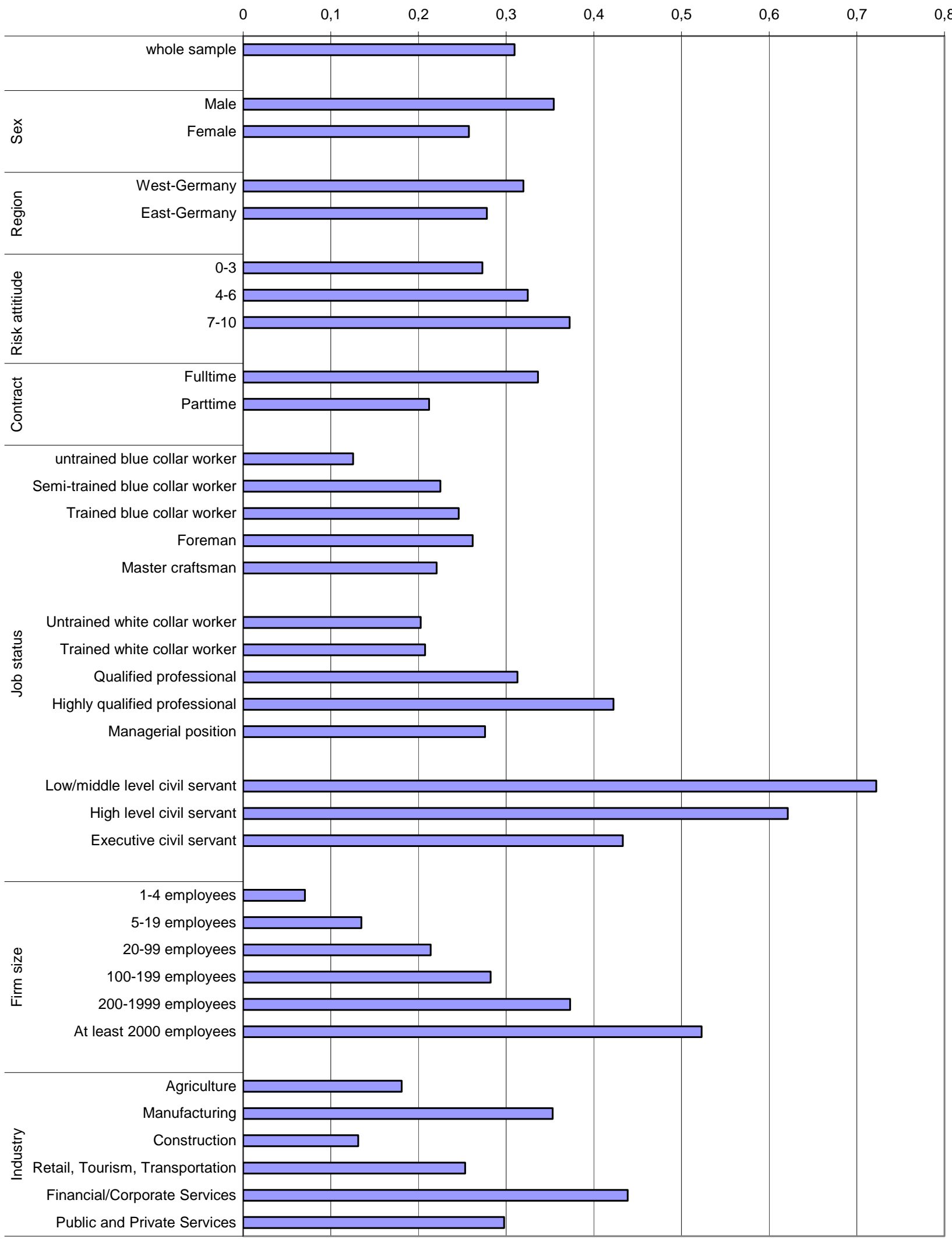


Table 3: Determinants of the Usage of PA - Binary Probit Regressions

\begin{tabular}{|c|c|c|c|c|c|c|}
\hline & \multicolumn{2}{|c|}{ (1) } & \multicolumn{2}{|c|}{ (2) } & \multicolumn{2}{|c|}{ (3) } \\
\hline Sex (female) & $-0.258 * * *$ & $(8.33)$ & & & $-0.102 * *$ & $(2.52)$ \\
\hline Age & -0.002 & (1.39) & & & $-0.003 *$ & $(1.66)$ \\
\hline Years of Schooling & $0.055^{* * *}$ & (9.44) & & & -0.003 & $(0.41)$ \\
\hline Employee's risk attitude & $0.034 * * *$ & (5.42) & & & $0.029 * * *$ & (4.18) \\
\hline Part-time & & & $-0.161 * * *$ & (3.63) & $-0.093 *$ & (1.93) \\
\hline East-Germany & & & 0.038 & $(0.97)$ & 0.046 & (1.17) \\
\hline Tenure (in years) & & & $-0.004^{* *}$ & $(2.54)$ & -0.002 & $(0.76)$ \\
\hline \multicolumn{7}{|c|}{ Job status (base: untrained blue collar worker): } \\
\hline Semi-trained blue collar worker & & & $0.261^{* *}$ & (2.17) & $0.244^{* *}$ & $(2.02)$ \\
\hline Trained blue collar worker & & & $0.397 * * *$ & (3.33) & $0.340 * * *$ & $(2.81)$ \\
\hline Foreman & & & $0.402 * *$ & (2.49) & $0.318^{*}$ & (1.95) \\
\hline Master craftsman & & & $0.345^{* *}$ & $(2.05)$ & 0.269 & (1.59) \\
\hline Untrained white collar worker & & & $0.455^{* * *}$ & (3.29) & $0.439 * * *$ & (3.16) \\
\hline Trained white collar worker & & & $0.428 * * *$ & (3.47) & $0.403 * * *$ & (3.23) \\
\hline Qualified professional & & & $0.579 * * *$ & (5.08) & $0.551 * * *$ & (4.74) \\
\hline Highly qualified professional & & & $0.769 * * *$ & $(6.56)$ & $0.715^{* * *}$ & (5.71) \\
\hline Managerial position & & & $0.465^{* * *}$ & $(2.83)$ & $0.385^{* *}$ & $(2.26)$ \\
\hline Low/middle level civil servant & & & $1.624 * * *$ & $(10.78)$ & $1.541^{* * *}$ & $(10.04)$ \\
\hline High level civil servant & & & $1.448^{* * *}$ & $(10.32)$ & $1.387 * * *$ & $(9.40)$ \\
\hline Executive civil servant & & & $1.085^{* * * *}$ & $(6.72)$ & $1.035^{* * *}$ & (5.96) \\
\hline \multicolumn{7}{|l|}{ Industries (base: Construction): } \\
\hline Agriculture & & & 0.301 & $(1.61)$ & $0.309 *$ & (1.65) \\
\hline Manufacturing & & & $0.398 * * *$ & $(4.54)$ & $0.414 * * *$ & $(4.70)$ \\
\hline Retail/Tourism/Transportation & & & $0.190 * *$ & $(2.06)$ & $0.205^{* *}$ & $(2.22)$ \\
\hline Financial/Corporate Services & & & $0.590 * * *$ & (6.09) & $0.616^{* * *}$ & (6.31) \\
\hline Public and private Services & & & 0.041 & $(0.45)$ & 0.085 & $(0.92)$ \\
\hline \multicolumn{7}{|l|}{ Firm Size (base: 1-4 employees): } \\
\hline 5-19 employees & & & $0.338 * * *$ & (3.41) & $0.334 * * *$ & (3.37) \\
\hline 20-99 employees & & & $0.583^{* * *}$ & $(6.10)$ & $0.576^{* * *}$ & $(6.02)$ \\
\hline 100-199 employees & & & $0.783 * * *$ & (7.69) & $0.775^{* * *}$ & $(7.61)$ \\
\hline 200-1999 employees & & & $1.019 * * *$ & $(10.77)$ & $1.005^{* * *}$ & $(10.61)$ \\
\hline At least 2000 employees & & & $1.315^{* * *}$ & (13.91) & $1.297 * * *$ & $(13.67)$ \\
\hline Intercept & $-1.123^{* * *}$ & $(10.86)$ & $-2.099 * * *$ & $(12.92)$ & $-2.008 * * *$ & $(9.97)$ \\
\hline Observations & 7598 & & 7598 & & 7598 & \\
\hline Log-Likelihood & -4589.96 & & -4066.17 & & -4050.98 & \\
\hline Pseudo R-squared & 0.02 & & 0.14 & & 0.14 & \\
\hline
\end{tabular}

Notes: Absolute t-statistics in parentheses. ${ }^{*}, * *$ and $* * *$ indicate significance at the $0.10,0.05$ and 0.01 level. 


\subsection{I mpact of Performance Appraisals on Bonuses and Future Promotions}

As stated in section 2, appraisals can be implemented for several reasons. Possible consequences include direct monetary rewards such as monthly or yearly bonus payments as well as indirect career prospects in the form of an increased probability of future promotions after a favourable appraisal. Hence, we will examine these aspects in the following by analysing the relevance of PA on bonuses and future promotions and its individual and job based influencing factors. ${ }^{3}$ We therefore restrict the analysis of this subsection to individuals, whose performance is appraised. Because of some non-respondents the number of observations differ slightly between the examination of bonus payments $(n=2168)$ and promotion prospects $(\mathrm{n}=2026)$.

Of those individuals whose performance is appraised systematically 37 per cent report an impact on bonus payments and 54 per cent on future promotions. A considerable number of employees report an impact on both bonuses and promotions (0.23).

First, we investigate the impact of PA on bonus payments. As indicated by Figure 2 the impact is more relevant for male employees and less relevant for part-time employees. It is increasing in firm size and in the job status of white collar employees. But interestingly, starting from a low level, it is decreasing in the job status of civil servants.

There are substantial industry effects: More than $50 \%$ of all employees whose performance is appraised in financial and corporate services receive bonus payments contingent on these appraisals. But less than $20 \%$ get systematic evaluations by a superior in public and private services.

The impact on future promotions is depicted in Figure 3. In contrast to the low impact of PA on bonuses for civil servants, promotion prospects are highly affected by PA for this group. The relative patterns with respect to gender, region, risk attitude, type of contract and firm size are similar to the impact on bonus payments.

To test these observations we again investigated binary probit regressions separately on the impact on bonus payments and on future promotions (see Table 3). The results mainly confirm the above observations. Note that the impact of performance appraisals on future promotions decreases with age, while the impact on bonus payments is not affected by age.

\footnotetext{
${ }^{3}$ Unfortunately, the data do not include information on other possible consequences such as training issues.
} 
The probability of being promoted will decrease close to the retirement age but bonus payments can still be an effective incentive instrument for old employees. 
Figure 2: Percentage of individuals, whose PA has an impact on bonus payment

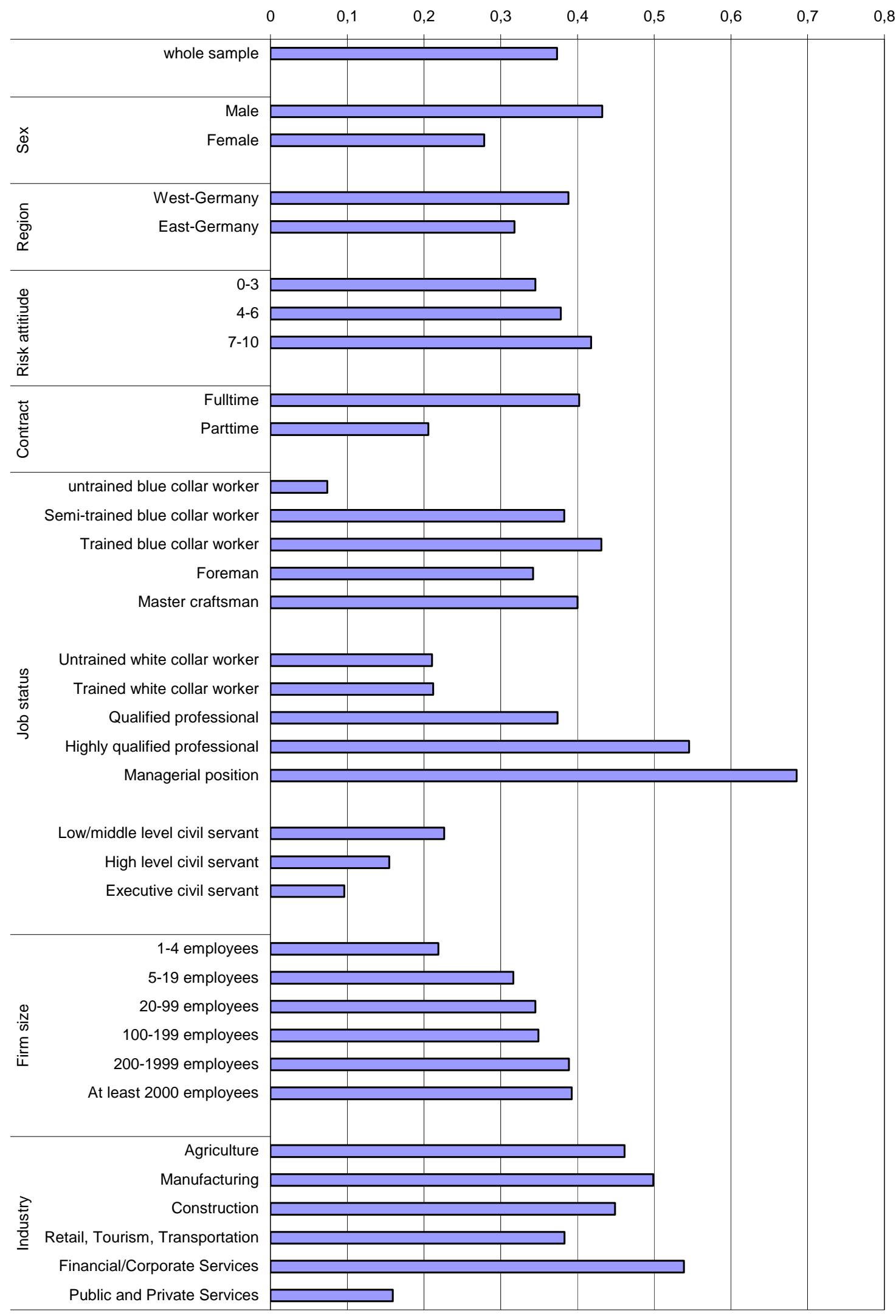


Figure 3: Percentage of individuals, whose PA has an impact on future promotions

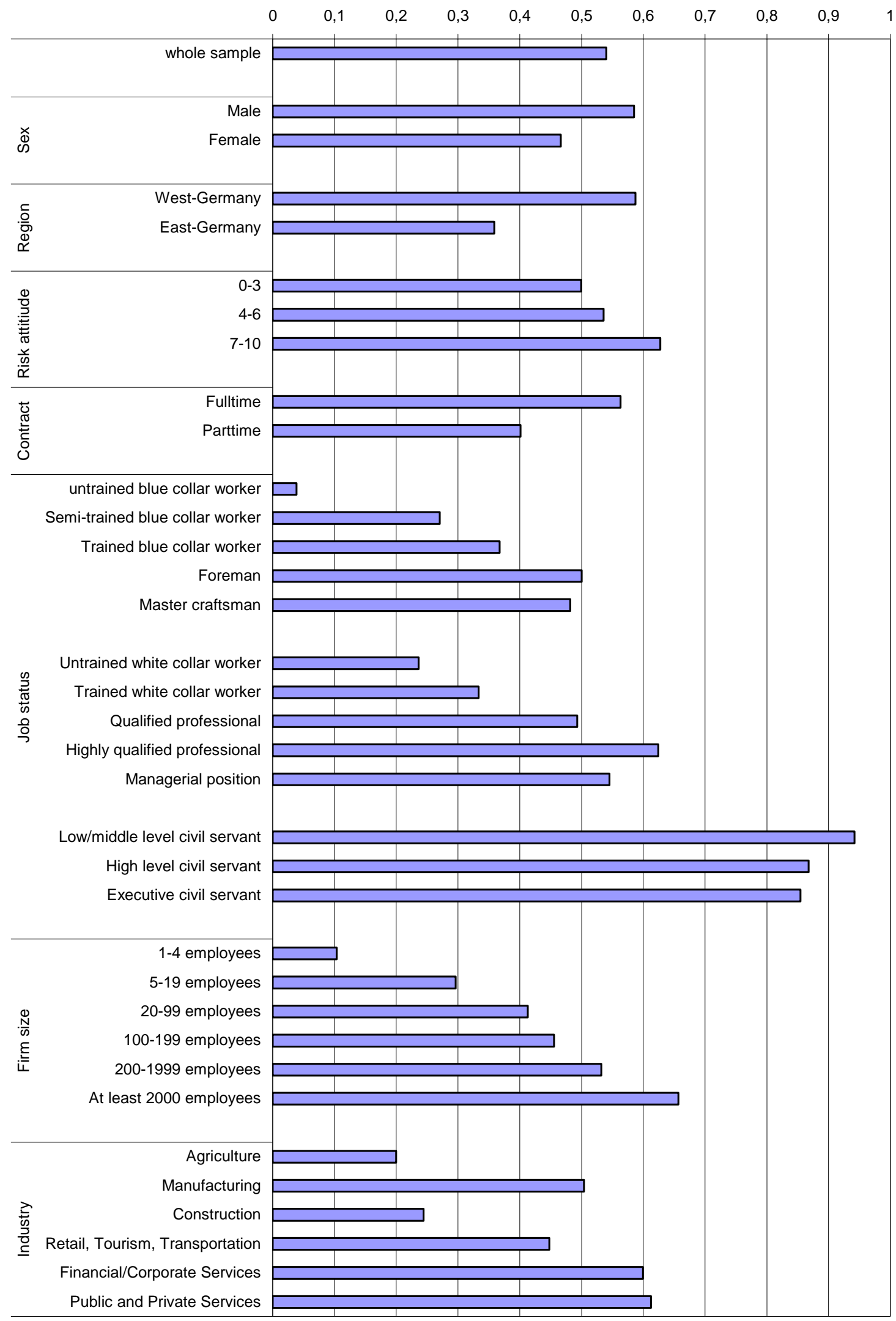


Interestingly, east German employees report a significantly lower impact of performance appraisals on promotions compared to their West German colleagues while there is no significant difference for bonus payments. Workers with part-time contracts receive bonus payments less often, while the result for future promotions is not significant.

The performance appraisal results become more and more important for future promotions the larger the firm size. On the one hand, this reflects lacking promotion possibilities in smaller firms without a pronounced hierarchical structure. But in addition, this may also well be the case because - as laid out above - in small owner-managed firms the employer knows most of his or her employees directly and do not need to rely on formal appraisals for promotion decisions.

Another quite surprising result from the probit estimations is that, contrary to the first observation based on the comparison of mean proportions in Figure 3, firm size does not seem to matter for the relevance of appraisals on bonus payments. In comparison to very small firms of less than 5 employees all other firms seem to have a higher probability of paying bonuses but (i) this difference is statistically insignificant and (ii) it is not increasing with firm size. Hence, smaller firms use performance appraisals less frequently than larger firms. But given that they do so, they make a similar use of these appraisals as a basis for bonus payments.

\section{Conclusion}

This study offers a first empirical examination of individual and job based determinants of performance appraisal usage. We have shown that both individual (sex, age, risk attitude) and job based (position, industry, firm size) aspects matter. Performance appraisals are used for different purposes. Appraisals are used for promotion decisions especially for civil servants, younger employees and in large firms. In about 37\% of those jobs in which performance appraisals are used these appraisals determine bonus payments made to individual employees. Bonuses are paid more frequently to white-collar, full-time male employees in particular.

Given the high practical importance of appraisal research it would be desirable for future research that much more detailed information concerning performance appraisals would become part of linked employer employee data sets over a longer period of time. This would allow a more detailed study not only on the determinants - such as has been done in this paper 
- but also consequences of performance appraisals for employees (e.g. with respect to wages, job satisfaction and fluctuation) and firms (with respect to productivity measures and financial performance). 
Table 4: Determinants of the impact of PA on bonus payments and possible future promotions - Binary Probit Regression

\begin{tabular}{llclc}
\hline & \multicolumn{3}{c}{ Bonus payments } & \multicolumn{2}{c}{ Future promotions } \\
\hline Sex (female) & $-0.160^{* *}$ & $(2.20)$ & $-0.136^{*}$ & $(1.76)$ \\
Age & 0.003 & $(0.65)$ & $-0.028^{* * *}$ & $(6.77)$ \\
Tenure (in years) & 0.001 & $(0.15)$ & -0.003 & $(0.70)$ \\
Years of Schooling & 0.021 & $(1.39)$ & -0.019 & $(1.19)$ \\
Part-time & $-0.277^{* * *}$ & $(2.72)$ & -0.162 & $(1.61)$ \\
East-Germany & -0.113 & $(1.47)$ & $-0.443^{* * *}$ & $(5.46)$ \\
Employee`s risk attitude & 0.014 & $(1.08)$ & 0.007 & $(0.51)$
\end{tabular}

Job status (base: untrained blue collar orker):

Semi-trained blue collar worker

$1.188^{* * *}$

(3.05)

$1.104 * *$

(2.28)

Trained blue collar worker

$1.231^{* * *}$

(3.18)

$1.375^{* * *}$

Foreman

$0.914 * *$

(2.10) 1.608***

(3.06)

Master craftsman

$1.103^{* *}$

(2.41)

$1.826^{* * *}$

Untrained white collar worker

$0.995^{* *}$

(2.33)

$1.212^{* *}$

Trained white collar worker

$0.992^{* *}$

(2.46)

$1.436 * * *$

$1.293 * * *$

(3.35)

$1.711^{* * * *}$

$1.572 * * *$

(4.02)

$2.091 * * *$

Highly qualified professional

$1.941^{* * *}$

(4.31)

Managerial position

$1.332 * * *$

(3.27)

$1.972 * * *$

Low/middle level civil servant

$1.056^{* *}$

(2.56)

$3.334 * * *$

(6.54)

High level civil servant

$0.810^{*}$

(1.73)

$3.052 * * *$

(6.08)

Executive civil servant

$3.264 * * *$

Industries (base: Construction):

Agriculture
Manufacturing
Retail, Tourism, Transportation
Financial/Corporate Services
Public and Private Services

Firm Size (base: 1 -4 employees):

\begin{tabular}{|c|c|c|c|c|}
\hline 5-19 employees & 0.363 & $(1.24)$ & 0.566 & $(1.55)$ \\
\hline 20-99 employees & 0.407 & $(1.46)$ & $0.700^{* *}$ & (1.98) \\
\hline 100-199 employees & 0.409 & (1.43) & $0.815^{* *}$ & $(2.26)$ \\
\hline 200-1999 employees & 0.368 & $(1.34)$ & $1.005^{* * *}$ & $(2.88)$ \\
\hline At least 2000 employees & 0.323 & (1.18) & $1.194 * * *$ & (3.42) \\
\hline Intercept & $-2.104 * * *$ & (3.83) & $-1.504 * *$ & (2.29) \\
\hline Observations & \multicolumn{2}{|c|}{2168} & \multicolumn{2}{|c|}{2028} \\
\hline Log-Likelihood & \multicolumn{2}{|c|}{-1246.5421} & \multicolumn{2}{|c|}{-1093.8372} \\
\hline Pseudo R² & \multicolumn{2}{|c|}{0.1300} & \multicolumn{2}{|c|}{0.2183} \\
\hline
\end{tabular}

Notes: Absolute t-statistics in parentheses. ${ }^{*}, * *$ and $* * *$ indicate significance at the $0.10,0.05$ and 0.01 level.

$\begin{array}{llll}0.219 & (0.50) & 0.181 & (0.31) \\ 0.097 & (0.49) & 0.414^{*} & (1.78) \\ -0.111 & (0.54) & 0.198 & (0.82) \\ 0.205 & (0.97) & 0.555^{* *} & (2.27) \\ -0.812^{* * *} & (3.88) & 0.242 & (1.01)\end{array}$




\section{References}

Bretz, R. D.; G. T. Milkovich; W. Read (1992): The Current State of Performance Appraisal Research and Practice: Concerns, Directions, and Implications. Journal of Management (18), 312-352.

Brown, M.; J. S. Heywood (2005): Performance Appraisal Systems: Determinants and Change. British Journal of Industrial Relations (43), 659-679.

Callahan, J. S.; A. L. Brownlee; M. D. Brtek; H. L. Tosi (2003): Examining the Unique Effects of Multiple Motivational Sources on Task Performance. Journal of Applied Social Psychology (33), 2515-2535.

Cleveland, J. N.; K. R. Murphy; R. E. Williams (1989): Multiple Uses of Performance Appraisal: Prevalence and Correlates. Journal of Applied Psychology (74), 130-135.

Holmström, B. and Milgrom, P. (1991): Multitask Principal-Agent Analyses: Incentive Contracts, Asset Ownership and Job Design. Journal of Law, Economics and Organization (7), 24-52.

Kerr, S. (1975): On the Folly of Rewarding A, While Hoping for B. Academy of Management Journal, 18(4): 769-783.

Kuvaas, B. (2006): Performance Appraisal Satisfaction and Employee Outcomes: Mediating and Moderating Roles of Work Motivation. International Journal of Human Resource Management (17), 504-522.

Levy, P. E.; J. R. Williams (2004): The Social Context of Performance Appraisal: A Review and Framework for the Future. Journal of Management (30), 881-905.

Murphy, K. J. (1999): Executive Compensation. In: Ashenfelter, O. and Card, D. (eds.), Handbook of Labor Economics, Vol. 3, North Holland.

Murphy, K. R. and Cleveland, J. N. (1995): Understanding Performance Appraisal. Thousand Oaks: Sage.

Murphy, K. J. and Oyer, P. (2003): Discretion in Executive Incentive Contracts. Working Paper. Stanford University.

Niederle, Muriel, and Lise Vesterlund (2007): Do Women Shy away from Competition? Do Men Compete too Much? Quarterly Journal of Economics.

Poon, J. M. L. (2004): Effects of Performance Appraisal Politics on Job Satisfaction and Turnover Intention. Personnel Review (33), 322-334. 